\title{
Antimicrobial Effects of Berries on Listeria monocytogenes
}

\author{
Elisaveta Sandulachi' ${ }^{1}$ Daniela Cojocari², Greta Balan², Liliana Popescu' ${ }^{1}$, \\ Aliona Ghendov-Moșanu1, Rodica Sturza ${ }^{1 *}$ \\ ${ }^{1}$ Technical University of Moldova, Chisinau, Republic of Moldova (RM) \\ "Nicolae Testemitanu" State University of Medicine and Pharmacies, Chisinau, Republic of Moldova (RM) \\ Email: *rodica.sturza@chim.utm.md
}

How to cite this paper: Sandulachi, E., Cojocari, D., Balan, G., Popescu, L., GhendovMoșanu, A. and Sturza, R. (2020) Antimicrobial Effects of Berries on Listeria monocytogenes. Food and Nutrition Sciences, 11, 873-886.

https://doi.org/10.4236/fns.2020.119061

Received: July 7, 2020

Accepted: September 18, 2020

Published: September 21, 2020

Copyright $\odot 2020$ by author(s) and Scientific Research Publishing Inc. This work is licensed under the Creative Commons Attribution International License (CC BY 4.0).

http://creativecommons.org/licenses/by/4.0/

\begin{abstract}
The purpose of this study was to first evaluate the antimicrobial effects of powder and extracts of berries (rose-hip, aronia, sea buckthorn and hawthorn) on the development of antibiotic-resistant L. monocitogenes. Listeria monocytogenes is considered one of the most important pathogens responsible for food-borne infection. Antimicrobial properties were evaluated using the standard Kirby-Bauer disk diffusion method. Bacterial inactivation networks were determined and compared, as well as the possibility of using powders and extracts of berries to control the risk of Listeria monocytogees infestation in the milk and dairy industry as well as in the meat industry. The effect of $\mathrm{pH}(4.78-4.43)$ and water activity $(0.90-0.80)$ on the relationship between optical density (OD) at $600 \mathrm{~nm}$ and the plate count $\left(\mathrm{CFU} \mathrm{ml} \mathrm{m}^{-1}\right)$ was investigated for Listeria monocytogenes. It was determined Minimum Inhibitory Concentration (MIC), Minimum Bactericidal Concentration (MBC) of berries for $L$. monocytogenes. The most relevant bacteriostatic and bactericidal effect on $L$. monocytogenes in the tested berries demonstrated sea buckthorn and rosehip.
\end{abstract}

\section{Keywords}

L. monocitogenes, Berries, Kirby-Bauer Test, Minimum Inhibitory Concentration (MIC), Minimum Bactericidal Concentration (MBC)

\section{Introduction}

Listeria monocytogenes is considered one of the most important pathogens responsible for food-borne infection. It is often incriminated in outbreaks of human listeriosis [1] [2]. Listeria monocytogenes is a foodborne pathogen that can cause invasive severe human illness (listeriosis) in susceptible patients. Most 
human listeriosis cases appear to be caused by consumption of refrigerated ready-to-eat foods [3]. In the European Union (EU), 1763 confirmed human cases of listeriosis were reported in 2013 by 27 member states. The EU notification rate was 0.44 cases per 100,000 population which represented an $8.6 \%$ increase compared to 2012 [4]. In 2013, there were 191 deaths caused by listeriosis in the EU. The highest number of fatal cases (64) was reported in France. Mortality rate in the EU was established at $15.6 \%$ among cases with known outcome. In 2013, a total of 13 outbreaks caused by L. monocytogenes were reported by seven MS and one non-MS. It was observed that the number of listeriosis in 2013 was slightly higher than in the previous years [5]. The European Food Safety Authority (EFSA) reported, in Europe, from 2008 to 2015, 37 food-borne outbreaks caused by L. monocytogenes that lead to 37 deaths [6]. Just from June of 2018, 47 cases have been reported, and nine patients have died due to or with the infection [7]. L. monocytogenes is an opportunistic bacterial pathogen that has the capacity to survive under extreme environmental conditions encountered in nature and in the food chain, such as high salt concentrations [8], large range of $\mathrm{pH}$ [9], desiccation [10] [11] and low temperatures [12].

In dairy industry, Listeria can contaminate directly or indirectly the products and the environment through contaminated raw milk, resulting in huge losses both in terms of public health and economy [2]. The presence of Listeria in yogurt may be a result of very bad quality of raw milk, inadequate heat treatment of milk or re-contamination as a result of using contaminated additives and poor hygiene during processing and packaging [13]. The pasteurization of milk has been recognized to ensure effective consumer safety against $L$. monocytogenes [14]. A study in Morocco [2] shows that out of 288 samples of dairy products examined, 17 (5.90\%) were found to be contaminated with L. monocytogenes. Boubendir et al. [15] reported 5.76\% prevalence of $L$. monocytogenes in bovine raw milk produced in the North Eastern Algeria. Similar results found by Guerra et al. [16], where the incidence of contamination was 5\% in milk and dairy products sold in mainland Portugal. Gaya et al. [17] reported also a low incidence of $3.6 \%$ of $L$. monocytogenes in raw milk produced in Spain. Whereas in China, the prevalence of $L$. monocytogenes in raw milk is very low $(0.23 \%$ to 1.2\%) [18]. Benkerroum et al. [19] reported that bacteriocins produced by the lactic acid bacteria reduce counts of $L$. monocytogenes in cheese and yoghurt. Furthermore, several authors have confirmed that the growth or survival of $L$. monocytogenes in a food product depends on a variety of physico-chemical parameters, including $\mathrm{pH}, \mathrm{a}_{\mathrm{w}}$ and $\mathrm{NaCl}$ content [20] [21].

Listeria monocytogenes is a psychrotrophic microorganism (able to grow and multiply during cold storage) and even a few cells present in the final product can multiply to a level that is dangerous to consumers [22]. On the basis of literature data [23] [24], it can be concluded that L. monocytogenes has unfavourable conditions for growth in yogurt. However, these bacteria may survive in the final product for definite time depending on the type of product, its characteris- 
tics (e.g. pH, competitive microflora), storage conditions (temperature) and other environmental circumstances. Previous studies have specifically shown that L. monocytogenes does not grow at a $\mathrm{pH}$ below 5.3 when the $\mathrm{a}_{\mathrm{w}}$ is lower than 0.93 [25], or at a pH below 4.46 regardless of the $a_{w}$ [8] [26]. In our study, the average physicochemical parameters associated with Lben and Jben are as such that they should limit (if not prevent) the growth of L. monocytogenes. The poor hygienic conditions during milking, transport, storage of milk and its use in the manufacture of Lben and Jben in traditional dairies, which do not respect the principles of food hygiene, can also be in favor of the contamination with $L$. monocytogenes [2]. When L. monocytogenes is present in a large number in raw milk some cells may survive the production process of yogurt and pose a serious hazard for consumers health [23]. Control of the feeding cattle, the general principles of food hygiene and milk pasteurization limit the contamination with $L$. monocytogenes [2]. Understanding the behavior of Listeria monocytogenes in fermented dairy products constitute sa crucial knowledge for Microbiological Risk Assessment (MRA) process, as well as Hazard Analysis and Critical Control Point (HACCP) system [23]. The experimental data regarding survival or inactivation of this foodborne pathogen during production and cold storage of yogurt at different temperatures can be described mathematically by predictive models [4] [27] [28] [29].

Predictive microbiology is based on the premise that the response of microorganisms to environmental factors is reproducible [4]. By defining the parameters that have the strongest effect on the behavior of microorganisms, it is possible to predict the response of microorganisms based on the performed observations [4] [30] [31]. L. monocytogenes is a Gram-positive, non-sporeforming foodborne pathogen, which is cold tolerant, widespread in the environment, and has the capability to grow under harsh conditions, including at elevated salt levels (up to 14\%). Listeria has been known to persist in the food production environment for prolonged periods, despite regular sanitation [32]. The gram-positive bacterium Listeria monocytogenes is recognized as a food-borne pathogen with significance for humans [33], and major outbreaks of infection have been linked to the consumption of contaminated coleslaw [34], cheeses [35] and pasteurized milk [36]. The innate resistance of L. monocytogenes to many of the food preservation systems that are effective against other food-borne pathogens has prompted research aimed at developing combination systems for more effective control of this pathogen [37]. The purpose of the study was to determine the antibacterial activity of powder and extracts of berries (rose-hip, aronia, sea buckthorn and hawthorn) on L. monocytogenes.

\section{Materials and Methods}

Materials: extracts and powder berries - sea buckthorn, rose-hip, aronia and hawthorn. The test products were dissolved: $1 \mathrm{~g}$ produced in $4 \mathrm{ml}$ of physiological solution, After which dilutions were made. Concentration of test 
substances: 1 - $250 \mathrm{mg} / \mathrm{ml} ; 2$ - $125 \mathrm{mg} / \mathrm{ml} ; 3$ - $62.5 \mathrm{mg} / \mathrm{ml} ; 4$ - $31.25 \mathrm{mg} / \mathrm{ml}$.

Initial concentration of preparations (liquids) of berries: sea buckthorn -0.12 $\mathrm{mg} / 100 \mathrm{ml}$; rose-hip $-0.15 \mathrm{mg} / 100 \mathrm{ml}$; aronia $-0.18 \mathrm{mg} / 100 \mathrm{ml}$; hawthorn -0.20 $\mathrm{mg} / 100 \mathrm{ml}$.

Product. Experimental samples (yogurt control and yogurt with addition (extracts and powder) of aronia were prepared in laboratory conditions in the Food Technology Department. Raw cow milk, obtained from local farm was received according to Governmental Decision No. 158, on 07.03.2019 with regard to the approval of the Technical Regulation "Milk and dairy products" that included technical conditions for the quality of raw cow milk collected for industrial processing [38]. The milk was pasteurized and standardized to a fat content of $2.5 \%$. The milk was pasteurized $\left(95^{\circ} \mathrm{C} / 30 \mathrm{~min}\right)$, cooled to $45^{\circ} \mathrm{C}$ and inoculated with $1.5 \%$ starter culture consisting of Lactobacillus delbrueckii ssp. bulgaricus and Streptococcus salivarius spp. Thermophiles (yogurt control) and yogurt with the addition (extracts and powder) - different concentrations of aronia. Notify the probe: Y-yogurt (control); YA 0.5 -yogurt with $0.5 \%$ aronia powder; YA 0.75 -yogurt with $0.75 \%$ aronia powder; YA 1.0 - yogurt with $1.0 \%$ aronia powder.

Test strain: L. monocytogenes ATCC 19118; Listeria monocytogenes EGDe Mc Farland $0.5\left(10^{5}\right)$ of L. monocytogenes strain ATCC 19118. Triptone Soya Broth (Oxoid) 6\%, TSA-Triptone Soya Agar (Oxoid).

\section{Methods: Antimicrobial Testing of extracts and powder berries}

Well diffusion method:

In this study we used the agar diffusion procedure, called well diffusion method, it is a qualitative method used to determine antibacterial activity of the tested substances (extracts and powder from berries) on tested strain. Previously, the tested strain of listeria was spread with the swab on the surface of the plate. Then, $8 \mathrm{~mm}$ diameter wells were made in the Mueller Hinton agar plate. The dissolved extracts were introduced into each well. If the bacterial strain is susceptible to the antimicrobial agent, then a transparent area is observed around the well. This area represents the inhibition zone of growth. If the bacteria is resistant to the antimicrobial agent around the well will be observed growth. The sensitivity or resistance of bacteria were calculated by measuring the inhibition zone diameter around the wells. The antimicrobial activity is calculated in millimeter: the total diameter of growth inhibited zone minus diameter of the well [39].

$1 \mathrm{~g}$ of yogurt was added 1 - 2 drops of microbial suspension according to the Mc Farland $0.5\left(10^{5}\right)$ turbidity standard from L. monocytogenes strain ATCC 19118. The infected samples were incubated in thermostat at $37^{\circ} \mathrm{C}$ for 24,48 hours and respectively 15 days.

Identification of minimum inhibitory concentration (MIC) The methodology for this experiment is based on the work of Lambert and others [40]. Ten $\mu \mathrm{L}$ of inoculum were dispensed in each well. After inoculation, the plate was incubated at $25^{\circ} \mathrm{C}$ for $24 \mathrm{~h}$ and the optical density (O.D.) of each well was recorded at $600 \mathrm{~nm}$ every $20 \mathrm{~min}$ after shaking [41]. 


\section{Identification of minimum bactericidal concentration ( $M B C$ )}

The methodology described below is an adaptation of the Minimum Bactericidal Concentration Testing from the Clinical Microbiology Procedures Handbook [42]. L. monocytogenes was cultured on tryptone soya (TS) agar plate at $37^{\circ} \mathrm{C}$ for $18 \mathrm{~h}$, and a cellular suspension was prepared in sterile distilled water.

\section{Results and Discussions}

Listeria monocytogenes is considered one of the most important pathogens responsible for foodborne infection. It is often incriminated in outbreaks of human listeriosis [1]. A number of studies have demonstrated that L. monocytogenes is more acid tolerant than most food-borne pathogens, although the sensitivity of the organism to organic acids varies with the nature of the acidulant used [43], Listeria spp. prefers to grow at $\mathrm{pH} 7-8$ but they will grow in the range pH $5-10$ and may survive and grow in material with a $\mathrm{pH}$ as low as 4.4 (Table 1). Results of another study demonstrate a high risk associated with consumption of bulked raw milk and fermented dairy products in due to occurrence of Listeria spp. [44].

In previous studies [46] [47] it has been found that sea buckthorn, rose-hip, aronia and hawthorn have antimicrobial effects on pathogenic microorganisms. Following the tests, the authors established that the additives of rose and hawthorn in the sausage recipe can control the growth rate of microorganisms, including pathogens. By studying the Lag and Logarithmic growth phases of pathogenic microbial strains we determined that the hawthorn has a greater bacteriostatic effect on strains of $S$. aureus ATCC 25923 and E. coli ATCC 25922 and the rose-hip has a greater bacteriostatic effect on Salmonella strains Abony ATCC 6017, Klebsiella pneumoniae ATCC 13883. The most relevant antimicrobial effect was seen for berry powders on $E$. coli strains inoculated in tested cream cheese samples. The additions of rose-hip and aronia powders manifested major antimicrobial effect on Salmonella strains. The addition of hawthorn powder manifested major antimicrobial effect on Staphylococcus aureus [46].

The results of the minimal inhibitory concentration (MIC) and minimal bactericidal concentration (MBC) for L. monocitogenes strain are presented in Table 2, Table 3. The results of the study showed that aronia and hawthorn have no antimicrobial activity against $L$. monocytogenes. Significant positive results showed the extracts and powders of sea buckthorn and rose-hip.

It has been studied whether berries have bactericidal effect on L. monocytogenes in food (yogurt). Yogurt samples (I) were infected with $L$. monicytogenes, the initial concentration being $10^{5}$ cells. After 24, 48 hours a decrease in bacteria was found in all samples, including in the control sample, without the addition of berries. After 15 days the samples were tested and it was found that L. monocytogenes was not present (Table 4). In the samples where additions of berries (extracts and powders) were introduced, the rate of reduction was much higher. The bactericidal effect of berries has been demonstrated. 
Table 1. Factors identified to have an impact on the growth and survival of L. monocytogenes $^{\mathrm{a}}$ (adapted from SANCO [45]).

\begin{tabular}{lllll}
\hline Factor & $\begin{array}{l}\text { Lower Growth } \\
\text { Limit }\end{array}$ & Optimum $^{\mathrm{b}}$ & $\begin{array}{l}\text { Upper Growth } \\
\text { Limit }\end{array}$ & $\begin{array}{l}\text { Can Survive } \\
\text { (No Growth) }\end{array}$ \\
\hline Temperature $\left({ }^{\circ} \mathrm{C}\right)$ & -1.5 to +3.0 & 30.0 to 37.0 & 45.0 & -18.0 \\
$\mathrm{pH}^{\mathrm{d}}$ & 4.2 to 4.3 & 7.0 & 9.4 to 9.5 & 3.3 to 4.2 \\
Water Activity $\left(\mathrm{a}_{\mathrm{w}}\right)$ & 0.90 to 0.93 & 0.99 & $>0.99$ & $<0.90$ \\
Salt Concentration ${ }^{\mathrm{e}}(\%)$ & $<0.5$ & 0.7 & $12-16$ & $\geq 20$
\end{tabular}

Atmosphere

Facultative anaerobe (it can grow in the presence or absence of oxygen, e.g. in a vacuum or modified atmosphere package)

Heat Treatment during

A temperature/time combination e.g. of $70^{\circ} \mathrm{C}$ and $2 \mathrm{~min}$ is required for

Food Processing a D6 (i.e. 106 or 6 decimal) reduction in numbers of L. monocytogenes cells. Other temperature/time combinations may also provide the same reduction

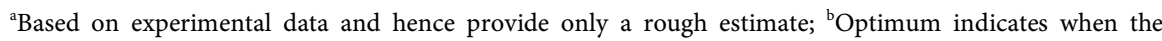
growth of L. monocytogenes is fastest; 'Survival period will vary depending on nature of food and other factors; ${ }^{\mathrm{d}}$ Inhibition of L. monocytogenes is dependent on type of acid present; ${ }^{\mathrm{e}} \mathrm{Based}$ on percent sodium chloride, water phase.

Table 2. MIC and MBC L. monocytogenes ATCC 19118.

\begin{tabular}{|c|c|c|c|c|c|}
\hline \multirow{2}{*}{ Nr. } & \multirow{2}{*}{ Berries } & \multicolumn{4}{|c|}{ Diameter of the complete growth inhibition zone (mm) } \\
\hline & & $250 \mathrm{mg} / \mathrm{ml}$ & $125 \mathrm{mg} / \mathrm{ml}$ & $62.5 \mathrm{mg} / \mathrm{ml}$ & $31.25 \mathrm{mg} / \mathrm{ml}$ \\
\hline 1. & $\begin{array}{c}\text { Sea buckthorn } \\
\text { (extract })\end{array}$ & $22.5 \pm 0.25$ & $19.25 \pm 0.22$ & $14.25 \pm 0.22$ & $10.75 \pm 0.22$ \\
\hline 2. & $\begin{array}{c}\text { Sea buckthorn } \\
\text { (powder) }\end{array}$ & $16.33 \pm 0.26$ & $12.5 \pm 0.25$ & $10.75 \pm 0.22$ & $0.0 \pm 0.0$ \\
\hline 5. & $\begin{array}{l}\text { Rose-hip } \\
(\text { extract })\end{array}$ & $16.33 \pm 0.26$ & $12.25 \pm 0.22$ & $10.25 \pm 0.22$ & $0.0 \pm 0.0$ \\
\hline 6. & $\begin{array}{l}\text { Rose-hip } \\
\text { (powder) }\end{array}$ & $17.75 \pm 0.42$ & $15.75 \pm 0.22$ & $11.75 \pm 0.22$ & $0.0 \pm 0.0$ \\
\hline
\end{tabular}

Table 3. The diameter of the complete growth inhibition zone of different species of $L$. monocytogenes under the action of the extract and powder of sea buckthorn rose-hip.

\begin{tabular}{|c|c|c|c|c|}
\hline \multirow{3}{*}{ Nr. } & \multirow{3}{*}{ Berries } & $\begin{array}{l}\text { L. monocytogenes } \\
\text { ATCC } 19118\end{array}$ & \multirow{3}{*}{ Berries } & $\begin{array}{c}\text { L. monocytogenes } \\
\text { EGDe }\end{array}$ \\
\hline & & $\begin{array}{c}\text { Diameter of the } \\
\text { complete growth } \\
\text { inhibition zone }(\mathrm{mm})\end{array}$ & & $\begin{array}{c}\text { Diameter of the } \\
\text { complete growth } \\
\text { inhibition zone }(\mathrm{mm})\end{array}$ \\
\hline & & $250 \mathrm{mg} / \mathrm{ml}$ & & $250 \mathrm{mg} / \mathrm{ml}$ \\
\hline 1. & $\begin{array}{l}\text { Sea buckthorn } \\
\text { (extract) }\end{array}$ & $22.25 \ldots 22.75$ & $\begin{array}{c}\text { Sea buckthorn } \mathrm{C}_{1}, \mathrm{C}_{2} \\
\text { (concentrated } \\
\text { hydroalcoholic extract) }\end{array}$ & $30 \ldots 32$ \\
\hline 2. & $\begin{array}{l}\text { Sea buckthorn } \\
\text { (powder) }\end{array}$ & $16.07 \ldots 16.59$ & $\begin{array}{c}\text { Sea buckthorn } \mathrm{H}_{1}, \mathrm{H}_{2} \\
\text { (hydroalcoholic extract) }\end{array}$ & $29 \ldots 30$ \\
\hline 5. & $\begin{array}{l}\text { Rose-hip } \\
\text { (extract) }\end{array}$ & $16.07 \ldots 16.59$ & $\begin{array}{c}\text { Rose-hip } \mathrm{C}_{1}, \mathrm{C}_{2} \\
\text { (concentrated } \\
\text { hydroalcoholic extract) }\end{array}$ & $20 \ldots 21.5$ \\
\hline 6. & $\begin{array}{l}\text { Rose-hip } \\
\text { (powder) }\end{array}$ & $17.33 \ldots 18.17$ & $\begin{array}{c}\text { Rose-hip } \mathrm{H}_{1}, \mathrm{H}_{2} \\
\text { (hydroalcoholic extract) }\end{array}$ & $22 \ldots 22$ \\
\hline
\end{tabular}


Table 4. The influence of different concentrations of aronia on the bactericidal effect ( $L$. monocitogenes) in yogurt.

\begin{tabular}{ccccc}
\hline \multirow{2}{*}{ The product tested } & \multicolumn{4}{c}{ L. monocytogenes, In $N$} \\
\cline { 2 - 5 } & $\begin{array}{c}\text { initially infected } \\
\text { with bacteria }\end{array}$ & 1 day & 2 days & 15 days \\
\hline Y & 11.51 & 6.40 & 6.55 & -9.21 \\
YA 0.5 & 11.51 & 4.80 & 5.58 & -9.21 \\
YA 0.75 & 11.51 & 3.61 & 4.16 & -9.21 \\
YA 1.0 & 11.51 & 5.58 & 5.24 & -9.21 \\
YA 0.5 & 11.51 & 4.88 & 3.61 & -9.21 \\
YA 0.75 & 11.51 & 5.46 & 4.30 & -9.21 \\
YA 1.0 & 11.51 & 5.02 & 2.20 & -9.21 \\
\hline
\end{tabular}

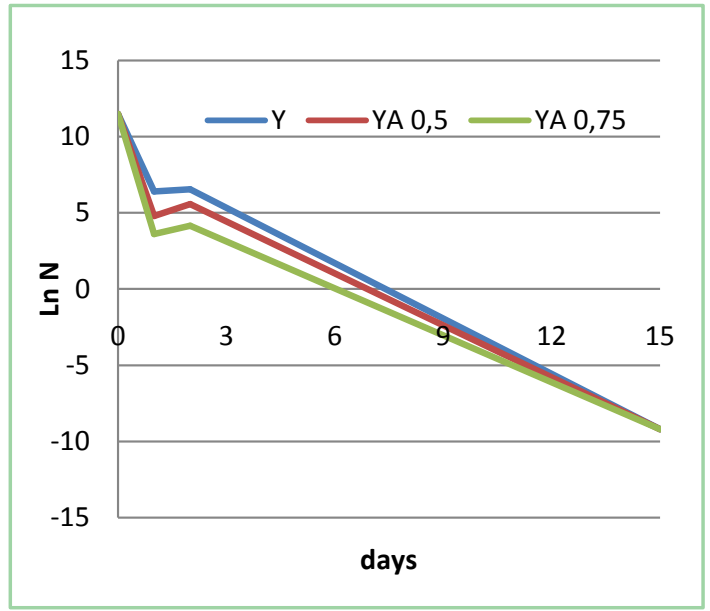

Results have been obtained that have been reported in other research studies. The main mechanism of bactericidal effect of yogurt on foodborne pathogens seems to be the decline in $\mathrm{pH}$ due to lactose fermentation by Lactobacillus delbrueckii ssp. bulgaricus and Streptococcus salivarius ssp. thermophilus added to milk as a starter culture, as well as the production of organic acids, mainly lactic acid [4] [48] [49]. The researchers found that lag phase and growth rate of Listeria were affected not only by storage temperature but also by lactic acid concentration and $\mathrm{pH}$ of product ranged from 5.2 do 5.8. J. Kowalik et al. [50] observed more dynamic growth of $L$. monocytogenes in milk samples, having a $\mathrm{pH}$ of 6.6, and stored under conditions identical to those applied for the samples of the cottage cheese. Some authors have suggested that antimicrobial activity of yogurt is not exclusively due to accumulation of lactic acid and may be also the effect of lactic acid and other compounds such as hydrogen peroxide, carbon dioxide, acetaldehyde, polysaccharide and bacteriocins [51]. The $\mathrm{pH}$ value of 4.6 is usually considered as a minimum $\mathrm{pH}$ permitting the growth of $L$. monocytogenes in food [52]. However, $\mathrm{pH}$ minimum as low as 4.39 has also been reported [53]. Low $\mathrm{pH}$ of the environment is an important factor responsible for the re- 
duction of Listeria population in yogurt, the correlation between the number of L. monocytogenes and $\mathrm{pH}$ amounted to 0.832 [4]. Listeria is one of the few foodborne pathogens that can multiply at low water activity. Studies have shown that this organism can multiply at $\mathrm{a}_{\mathrm{w}}$ below 0.93 [54] [55].

In the food industry, salting is a food preservation method designed primarily to obtain lower water activity. However, L. monocytogenes is able to survive high concentration of salt and is thus not an easy pathogen to control by osmotic stress alone. Osmo-adaptation in bacteria can involve both physiological changes and as well as regulation at the gene expression level [56].

The low counts observed in Bongo may be attributed to the low $\mathrm{pH}$ and other antimicrobial compounds such as bacteriocins produced by lactic acid bacteria. Also, the type of acid and the storage temperature have a marked effect on the ability of Listeria to survive and grow at low $\mathrm{pH}$. On the other hand, the presence of Listeria spp. in Bongo may be attributed to contamination from raw milk, the starter culture inoculum and slow rate of acid formation and $\mathrm{pH}$ decline [44].

A number of studies have demonstrated the inhibitory activity of organic acids against $L$. monocytogenes and have shown that the effects are mainly related to the amount of undissociated acid [57] [58] [59]. Benzoate and formate (used alone) they were highly effective at killing L. monocytogenes at $\mathrm{pH} 3$. Nevertheless, in all cases addition of ethanol resulted in shorter killing times. The most effective bactericidal combination, $5 \%$ ethanol and $50 \mathrm{mM}$ formate, resulted in 5 log units of killing in just 4 min [43]. A number of studies have demonstrated the inhibitory activity of organic acids against $L$. monocytogenes and have shown that the effects are mainly related to the amount of undissociated acid [57] [58] [59]. The most common way to assess microbial growth in solution is the measurement of the optical density at $600 \mathrm{~nm}$, or short $\mathrm{OD}_{600}$. The method is based on absorbance detection mode and basically determines which portion of light passes through a sample, more specifically through a suspension of microorganisms [60]. The calibration lines obtained by plotting $\log \mathrm{OD}_{600 \mathrm{~nm}}$ values vs. log plate counts showed high determination coefficients for all the tested strains in the range of $\mathrm{OD}_{600 \mathrm{~nm}}$ values $0.1-1.5$ corresponding to approximately $10^{6}-10^{9}$ $\mathrm{CFU} / \mathrm{ml}[61]$.

A case study was performed to determine the minimum inhibitory concentration (MIC) and the minimum bactericidal concentrations (MBC) of the extracts and powders of the dogwood and mulberry on $L$. monotogenes. The results of the study are presented in Table 5 .

The results of the study showed that hydroalcoholic extracts of sea buckthorn and rosehip showed beneficial results on the inhibitory and bactericidal effect of L. monocytogenes. The sea buckthorn has shown antimicrobial properties for L.monocytogenes more pronounced than rose-hip. Probably these properties are due to the chemical composition of sea buckthorn and rosehip. These berries are rich in organic acids. Determining the chemical composition of the rosehip, used in the case study, we found that the fruit contains: malic acid-154.3; citric 
Table 5. Minimum Inhibitory Concentration (MIC), Minimum Bactericidal Concentration (MBC) for L. monocytogenes EGDe.

\begin{tabular}{ccccc}
\hline & \multicolumn{3}{c}{ Sea buckthorn } & \multicolumn{2}{c}{ Rose-hip } \\
\cline { 2 - 5 } The tested \\
material & OD, & $\begin{array}{c}\text { Minimum Inhibitory } \\
\text { Concentration }(M I C), \\
\mathbf{m g / m l}\end{array}$ & OD, & $\begin{array}{c}\text { Minimum Inhibitory } \\
\text { Concentration }(M I C), \\
\mathbf{m g} / \mathbf{m l}\end{array}$ \\
\hline $\mathrm{C}_{1}$ & 0.071 & 2.6 & 0.059 & 4.2 \\
$\mathrm{C}_{2}$ & 0.047 & 5.2 & 0.053 & 16.7 \\
$\mathrm{H}_{1}$ & 0.061 & 2.6 & 0.020 & 4.2 \\
$\mathrm{H}_{2}$ & 0.072 & 2.6 & 0.024 & 4.2 \\
\hline
\end{tabular}

$\mathrm{C}_{1}, \mathrm{C}_{2}$-concentrated hydroalcoholic extract; $\mathrm{H}_{1}, \mathrm{H}_{2}$ - hydroalcoholic extract; DO-optical density.

acid-1684; succinic acid-56.89; lactic acid-30.54; acetic acid-23.85, including L-ascorbic acid- $72 \mathrm{mg} / 100 \mathrm{~g}$ s.u. Data recorded over the world, over time, show that dried rose hips contain ascorbic acid between $0.1 \%, 0.5 \%$ and $1.0 \%$, and some varieties even up to $9 \%$ [62].

In the study conducted by Tifrea Anca it was found that the addition of sea buckthorn pulp positively influences the increase of lactic acid content in yogurt [63]. The increase in lactic acid content may be due in part to the addition of sea buckthorn pulp due to the content of organic acids in it. Compared with the control sample which initially had 4.6 and finally 4.2 it can be seen that the addition of sea buckthorn influenced the $\mathrm{pH}$ by a greater decrease in the samples with higher addition of sea buckthorn in a similar way to acidity.

Another factor that would control the microbiological risk in food is water activity. Most bacterial species, including L. monocytogenes grow optimally at a water activity $\left(\mathrm{a}_{\mathrm{w}}\right)$ of 0.97 [45] [64]. Listeria monocytogenes is one of the few food-borne pathogens that can grow at an $a_{w}$ value below 0.93 [65]. However, $L$. monocytogenes also has the ability to grow to a level of $\mathrm{a}_{\mathrm{w}} 0.90$ [66]. In our case study it was found that in yogurt with the addition of powder rose hip the value $\mathrm{a}_{\mathrm{w}}$ was in the range of $0.876 \ldots 0.877$. The reduction in aw was also found in the samples of yogurt with the addition of sea buckthorn powder, compared to the control samples. This can probably be explained by the fact that bactericide was more prominent in yogurt with the addition of berries compared to classic yogurt. The cumulative effect of the quantitative and qualitative content of acids in the composition of sea buckthorn and rosehip extracts and powders and the property of reducing the $\mathrm{pH}$ and activity of water, make berries have bacteriostatic and bactericidal properties on Listeria monocytogenes.

\section{Conclusions}

Based on the study, sea buckthorn and rose-hip (extract and powder) were found to be excellent remedies for controlling the risk of L. monocytogenes infestation of food. This is due to the cumulative effect of the chemical composition of these berries (antioxidant content, organic acids, etc.), increased acidity, 
reduced $\mathrm{pH}$ and water activity of the food environment in which they were introduced below the development values of $L$. monocytogenes.

The minimum dose of inhibition and the minimum bactericidal dose of berries were determined. The use of added berry powders in the recipe for the production of dairy products can have two meanings: improving the nutritional value of the food and increasing the product shelf-life by keeping the microbiological risk under control, including L. monocytogenes.

\section{Acknowledgements}

The research was funded by State Project 20.80009.5107.09 "Improving of food quality and safety through biotechnology and food engineering", running at Technical University of Moldova.

\section{Conflicts of Interest}

The authors declare no conflicts of interest regarding the publication of this paper.

\section{References}

[1] Ryser, E.T. and Marth, E. (2007) Listeria, Listeriosis and Food Safety. 3rd Edition, Taylor and Francis, Boca Raton. https://doi.org/10.1201/9781420015188

[2] El Marnissi, B., Bennani, L., Cohen, N., et al. (2013) Presence of Listeria monocytogenes in Raw Milk and Traditional Dairy Products Marketed in the North-Central Region of Morocco. African Journal of Food Science, 7, 87-91. https://doi.org/10.5897/AJFS2013.0992

[3] Santos, T., et al. (2019) Listeria monocytogenes Biofilm Adaptation to Different Temperatures Seen through Shotgun Proteomics. Frontiers in Nutrition, 6, 89. https://doi.org/10.3389/fnut.2019.00089

[4] Szczawiński, J., Szczawińska, M.E., Łobacz, A. and Jackowska-Tracz, A. (2016) Modeling the Effect of Temperature on Survival Rate of Listeria monocytogenes in Yogurt. Polish Journal of Veterinary Sciences, 19, 317-324. https://doi.org/10.1515/pjvs-2016-0039

[5] EFSA European Food Safety Authority (2015) The European Union Summary Report on Trends and Sources of Zoonoses, Zoonotic Agents and Food-Borne Outbreaks in 2013. EFSA Journal, 13, 3991. https://doi.org/10.2903/j.efsa.2015.3991

[6] Ricci, A., Allende, A., Bolton, D., Chemaly, M., Davies, R., et al. (2018) Listeria monocytogenes Contamination of Ready-to-Eat Foods and the Risk for Human Health in the EU. European Food Safety Authority, Parma.

[7] EFSA (2018) Multi-Country Outbreak of Listeria monocytogenes Serogroup IVb, Multi-Locus Sequence Type 6. European Food Safety Authority, Parma.

[8] Cole, M.B., Jones, M.V. and Holyoak, C. (1990) The Effect of pH, Salt Concentration and Temperature on the Survival and Growth of Listeria monocytogenes. Journal of Applied Microbiology, 69, 63-72. https://doi.org/10.1111/j.1365-2672.1990.tb02912.x

[9] Davis, M.J., Coote, P.J. and O’byrne, C.P. (1996) Acid Tolerance in Listeria monocytogenes. The Adaptive Acid Tolerance Response (ATR) and Growth-Phase-Dependent Acid Resistance. Microbiology, 142, 2975-2982. https://doi.org/10.1099/13500872-142-10-2975 
[10] Vogel, B.F., Hansen, L.T., Mordhorst, H. and Gram, L. (2010) The Survival of Listeria monocytogenes during Long Term Desiccation Is Facilitated by Sodium Chloride and Organic Material. International Journal of Food Microbiology, 140, 192-200. https://doi.org/10.1016/j.ijfoodmicro.2010.03.035

[11] Santos, T., Theron, L., Chambon, C., et al. (2018) MALDI Mass Spectrometry Imaging and in Situ Microproteomics of Listeria monocytogenes Biofilms. Journal of Proteomics, 187, 152-160. https://doi.org/10.1016/j.jprot.2018.07.012

[12] Walker, S.J., Archer, P. and Banks, J.G. (1990) Growth of Listeria monocytogenes at Refrigeration Temperatures. Journal of Applied Microbiology, 68, 157-162. https://doi.org/10.1111/j.1365-2672.1990.tb02561.x

[13] Dzwolak, W., Ziajka, S., Chmura, S. and Baranowska, M. (2000) Manufacture of Milk Fermented Drinks. Biblioteczka Majstra Mleczarskiego. Oficyna Wydawnicza Hoża, Warsaw, 246-257.

[14] World Health Organization/Organisation Mondiale De La Santé (1988) Listerioses d'origine alimentaire. WHO/EHE/FOS/88.5, Geneve.

[15] Boubendir, A., Hamidechi, M.A., Mostakim, M., EL Abed, S. and Ibnsouda koraichi, S. (2011) Incidence de Listeria set autres bactéries psychrotrophes dans le lait cru bovin dans le Nord Est Algérien. Revue de Medecine Veterinaire, 162, 265-269.

[16] Guerra, M.M., Mclauchlin, J.M. and Bernardo, F.A. (2001) Listeria in Ready to Eat Unprocessed Foods Produced in Portugal. Food Microbiology, 18, 423-429. https://doi.org/10.1006/fmic.2001.0421

[17] Gaya, P., Sanchez, J., Medina, M. and Nuñez, M. (1998) Incidence of Listeria monocytogenes Sand Other Listeria Species in Raw Milk Produced in Spain. Food Microbiology, 15, 551-555. https://doi.org/10.1006/fmic.1997.0175

[18] Ning, N., Guo, K., Cheng, L., Xu, L., Zhang, C., Cui, H., Cheng, Y., Xu, R., Liu, W., Lv, Q., Cao, W. and Zhang, Y. (2013) Pilot Survey of Raw Whole Milk in China for Listeria monocytogenes Using PCR. Food Control, 31, 176-179. https://doi.org/10.1016/j.foodcont.2012.09.026

[19] Benkerroum, N., Oubel, H. and Sandine, W.E. (2003) Effect of Nisin on Yogurt Starter and on Growth and Survival of Listeria monocytogenes during Fermentation and Storage of Yogurt. Internet Journal of Food Safety, 1, 1-5.

[20] Conner, D.E., Brackett, R.E. and Beuchat, L.R. (1986) Effect of Temperature, Sodium Chloride, and $\mathrm{pH}$ on Growth of Listeria monocytogenes in Cabbage Juice. Applied and Environmental Microbiology, 52, 59-63. https://doi.org/10.1128/AEM.52.1.59-63.1986

[21] Learson, A.E., Johnson, E.A. and Nelson, J.H. (1999) Survival of Listeria monocytogenes in Commercial Cheese Brines. Journal of Dairy Science, 82, 1860-1868. https://doi.org/10.3168/jds.S0022-0302(99)75419-6

[22] Posfay-Barbe, K.M. and Wald, E.R. (2009) Listeriosis. Seminars in Fetal \& Neonatal Medicine, 14, 228-233. https://doi.org/10.1016/j.siny.2009.01.006

[23] Szczawiński, J., Stańczak, B. and Pęconek, J. (1998) Behaviour of Listeria monocytogenes in Fermented Milk Products-Prediction on the Basis of Experiments with Real Food Products and Pathogen Modeling Program V. 4.0. In: Shelf Life Prediction for Improved Safety and Quality of Foods, Copernicus Project CIPA-CT94-0120, Copi-Print Library Building University College, Dublin, 187-192.

[24] Lefoka, M. (2009) The Survival of Microbial Pathogens in Dairy Products. Master's Theses, University of the Free State, Bloemfontein, $161 \mathrm{p}$. http://scholar.ufs.ac.za:8080/xmlui/bitstream/handle/11660/1271/LefokaM.pdf;jsessi 
onid=DD8A3FAB608B9270B3CC28BAFD23E579? sequence $=1$

[25] Tienungoon, S., Ratkowsky, D.A., McMeekin, T.A. and Ross, T. (2000) Growth Limits of Listeria monocytogenes as a Function of Temperature, $\mathrm{pH}, \mathrm{NaCl}$, and Lactic Acid. Applied and Environmental Microbiology, 66, 4979-4987. https://doi.org/10.1128/AEM.66.11.4979-4987.2000

[26] Farber, J.M., Cai, Y. and Ross, W.H. (1996) Predictive Modeling of the Growth of Listeria monocytogenes in $\mathrm{CO}_{2}$ Environments. International Journal of Food Microbiology, 32, 133-144. https://doi.org/10.1016/0168-1605(96)01117-8

[27] Gibson, A.M., Bratchell, N. and Roberts, T.A. (1988) Predicting Microbial Growth: Growth Responses of Salmonellae in a Laboratory Medium as Affected by pH, Sodium Chloride and Storage Temperature. International Journal of Food Microbiology, 6, 155-178. https://doi.org/10.1016/0168-1605(88)90051-7

[28] Baranyi, J. and Roberts, T.A. (1994) A Dynamic Approach to Predicting Bacterial Growth in Food. International Journal of Food Microbiology, 23, 277-294. https://doi.org/10.1016/0168-1605(94)90157-0

[29] Hoang, H.M., Flick, D., Derens, E., Alvarez, G. and Laguerre, O. (2012) Combined Deterministic and Stochastic Approaches for Modeling the Evolution of Food Products along the Cold Chain. Part II: A Case Study. International Journal of Refrigeration, 35, 915-926. https://doi.org/10.1016/j.ijrefrig.2011.12.009

[30] Devlieghere, F., Francois, K., De Meulenaer, B. and Baert, K. (2006) Modelling Food Safety. In: Luning, P.A., Devlieghere, F. and Verhe, F., Eds., Safety in the Agri-Food Chain, Wageningen Academic Publishers, Wageningen, 397-417.

[31] Black, D.G. and Davidson, P.M. (2008) Use of Modelling to Enhance the Microbiological Safety of the Food System. Comprehensive Reviews in Food Science and Food Safety, 7, 159-167. https://doi.org/10.1111/j.1541-4337.2007.00034.x

[32] Keto-Timonen, R., et al. (2007) An 8-Year Surveillance of the Diversity and Persistence of Listeria monocytogenes in a Chilled Food Processing Plant Analyzed by Amplified Fragment Length Polymorphism. Journal of Food Protection, 70, 1866-1873. https://doi.org/10.4315/0362-028X-70.8.1866

[33] Farber, J.M. and Peterkin, P.I. (1991) Listeria monocytogenes, a Foodborne Pathogen. Microbiological Reviews, 55, 476-511. https://doi.org/10.1128/MMBR.55.3.476-511.1991

[34] Schlech, W.F., Lavigne, P.M., Bortolussi, R.A., Allen, A.C., Haldane, E.V., Wort, A.J., Hightower, A.W., Johnson, S.E., King, S.H., Nicholls, E.S. and Broome, C.V. (1983) Epidemic Listeriosis: Evidence for Transmission by Food. The New England Journal of Medicine, 308, 203-206. https://doi.org/10.1056/NEJM198301273080407

[35] James, S.M., Fanning, S.L., Agree, B.A., Hall, B., Parker, E., Vogt, J., Run, G., Williams, J., Lieb, L., Salminen, C., Prendergast, T., Werner, S.B. and Chin, J. (1985) Listeriosis Outbreak Associated with Mexican-Style Cheese-California. Morbidity and Mortality Weekly Report, 34, 357-359.

[36] Fleming, D.W., Cochi, S.L., MacDonald, K.L., Brondum, J., Hayes, P.S., Plikaytis, B.D., Holmes, M.B., Audurier, A., Broome, C.V. and Reingold, A.L. (1985) Pasteurized Milk as Vehicle of Infection in an Outbreak of Listeriosis. The New England Journal of Medicine, 312, 404-407. https://doi.org/10.1056/NEJM198502143120704

[37] Oh, D.-H. and Marshall, D.L. (1993) Antimicrobial Activity of Ethanol, Glycerol Monolaurate or Lactic Acid against Listeria monocytogenes. International Journal of Food Microbiology, 20, 239-246. https://doi.org/10.1016/0168-1605(93)90168-G

[38] Guvernul Republicii Moldova. Hotărîre Nr. 158 din 07.03.2019 cu privire la aprobarea 
Cerințelor de calitate pentru lapte și produsele lactate Publicat: 29.03.2019 în Monitorul Oficial Nr. 111-118 art Nr: 218.

[39] Walter, C., Shinvari, Z.K., Afzal, I. and Malik, R.N. (2011) Antibacterial Activity in Herbal Products Used in Pakistan. Pakistan Journal of Botany, 43, 155-162.

[40] Lambert, R.J.W. and Pearson, J. (2000) Susceptibility Testing: Accurate and Reproducible Minimum Inhibitory Concentration (MIC) and Non-Inhibitory Concentration (NIC) Values. Journal of Applied Microbiology, 88, 784-790. https://doi.org/10.1046/j.1365-2672.2000.01017.x

[41] Graph Pad Software Inc. (2006) Graph Pad Prism 4.00 for Windows. San Diego.

[42] Hindler, J. (1992) Antimicrobial Susceptibility Testing. In: Isenberg, H.D., Ed., Clinical Microbiology Procedures Handbook, Volume 1, American Society for Microbiology, Washington DC, 5.1.1-5.25.1.

[43] Barker, C. and Simon, F. (2001) Park Sensitization of Listeria monocytogenes to Low pH, Organic Acids, and Osmotic Stress by Ethanol. Applied and Environmental Microbiology, 67, 1594-1600. https://doi.org/10.1128/AEM.67.4.1594-1600.2001

[44] Mugampoza, D., et al. (2011) Occurrence of Listeria monocytogenes in Bulked Raw Milk and Traditionally Fermented Dairy Products in Uganda. African Journal of Food, Agriculture, Nutrition and Development, 11, 4610-4612.

http://www.bioline.org.br/abstract?id=nd11014 https://doi.org/10.4314/ajfand.v11i2.65916

[45] SANCO/1628/2008 Ver. 9.3 (26112008): Guidance Document on Listeria monocytogenes Shelf-Life Studies for Ready-to-Eat Foods, under Regulation (EC) No 2073/2005 of 15 November 2005 on Microbiological Criteria for Foodstuffs.

[46] Sturza, R., Sandulachi, E., Cojocari, D., Balan, G., Popescu, L. and Ghendov-Moșanu, A. (2019) Antimicrobial Properties of Berry Powders in Cream Cheese. Journal of Engineering Science, 26, 125-136.

[47] Cojocari, D., Sturza, R., Sandulachi, E., Macari, A., Balan, G. and Ghendov-Moșanu, A. (2019) Inhibiting of Accidental Pathogenic Microbiota in Meat Products with Berry Powders. Journal of Engineering Science, 26, 114-122.

[48] Rubin, H.E., Nerad, T. and Vaughan, F. (1982) Lactate Acid Inhibition of Salmonella Typhimurium in Yogurt. Journal of Dairy Science, 65, 197-203. https://doi.org/10.3168/jds.S0022-0302(82)82177-2

[49] Zagare, M.S., Deshmukh, A.M. and Patil, S.S. (2012) Analysis of Dairy Pack Food for Presence of Bacterial Pathogens. DA V International Journal of Science, 1, 25-28. https://citeseerx.ist.psu.edu/viewdoc/download?doi=10.1.1.300.5707\&rep=rep1\&typ e=pdf

[50] Kowalik, J., Łobacz, A. and Tarczyńska, S. (2013) Predicting Growth of Listeria monocytogenes Cell Count in Cottage Cheese. Żywność Nauka Technologia Jakość, 20, 37-48. https://doi.org/10.15193/zntj/2013/89/037-048

[51] Minj, A.K., et al. (2011) Antimicrobial Action of Yogurt against Some Pathogenic Microorganisms. Biohelica, 2, 67-71.

[52] Ray, B. and Bhunia, A. (2007) Control by Low pH and Organic Acids. In: Fundamental Food Microbiology, CRC Press, Boca Raton, 394.

[53] Corlett, D.A. and Brown, M.H. (1980) pH and Acidity. In: Microbial Ecology of Foods. Factors Affecting Life and Death of Microorganisms. International Commission on Microbiological Specification for Foods, Academic Press, Cambridge, 101.

[54] Farber, J.M., Coates, F. and Daley, E. (1992) Minimum Water Activity Requirements for the Growth of Listeria monocytogenes. Letters in Applied Microbiology, 15, 
103-105. https://doi.org/10.1111/j.1472-765X.1992.tb00737.x

[55] Petran, R.L. and Zottola, E.A. (1989) A Study of Factors Affecting Growth and Recovery of Listeria monocytogenes Scott A. Journal of Food Science, 54, 458-460. https://doi.org/10.1111/j.1365-2621.1989.tb03105.x

[56] Hill, C., Cotter, P.D., Sleator, R.D. and Gahan, C.G.M. (2002) Bacterial Stress in Listeria monocytogenes, Jumping the Hurdles Imposed by Minimal Processing. International Dairy Journal, 12, 273-283. https://doi.org/10.1016/S0958-6946(01)00125-X

[57] Buchanan, R.L. and Golden, M.H. (1998) Interactions between $\mathrm{pH}$ and Malic Acid Concentration on the Inactivation of Listeria monocytogenes. Journal of Food Safety, 18, 37-48. https://doi.org/10.1111/j.1745-4565.1998.tb00200.x

[58] Young, K.M. and Foegeding, P.M. (1993) Acetic, Lactic and Citric Acids and pH Inhibition of Listeria monocytogenes Scott A and the Effect on Intracellular $\mathrm{pH}$. Journal of Applied Microbiology, 74, 515-520.

[59] Yousef, A.E., El-Shenawy, M.A. and Marth, E.H. (1989) Inactivation and Injury of Listeria monocytogenes in a Minimal Medium as Affected by Benzoic Acid and Incubation Temperature. Journal of Food Science, 54, 650-652. https://doi.org/10.1111/j.1365-2621.1989.tb04673.x

[60] Stevenson, K., et al. (2016) General Calibration of Microbial Growth in Microplate Readers. Scientific Reports, 6, Article No. 38828. https://doi.org/10.1038/srep38828

[61] Krumm, A. (2019) Measure Microbial Growth Using the OD600. https://www.bmglabtech.com/measure-microbial-growth-using-the-od600

[62] Arsenescu-Popa, A., Mladin, P. and Popescu, H. (2008) Pharmacy Study. Study to Update the Monograph of the Medicinal Product Cynosbati Fructus (Rosehip). Craiova Medicală, 10, 121-124. (In Romanian) http://www.umfcv.ro/files/1/2/125695.pdf

[63] Țifrea, A.M. (2012) Research on Improving the Quality and Nutritional Properties of Dairy Products with the Addition of Bioactive Natural Products. Abstract of the Doctoral Thesis, "Lucian Blaga” University of Sibiu, Sibiu, 69 p. (In Romanian)

[64] Sandulachi, E. (2020) Water Activity in Food Products. Monograph, Chisinau, Ed. Tehnica-UTM, 207 p. (In Romanian)

[65] Farber, J.M., Coates, F. and Daley, E. (1992) Minimum Water Activity Requirements for the Growth of Listeria monocytogenes. Letters in Applied Microbiology, 15, 103-105. https://doi.org/10.1111/j.1472-765X.1992.tb00737.x

[66] Lado, B. and Yousef, A.E. (2007) Characteristics of Listeria monocytogenes Important to Food Processors. In: Ryser, E.T. and Marth, E.H., Eds., Listeria, Listeriosis and Food Safety, 3rd Edition, CRC Press, Boca Raton, Ch. 6, 157-213. https://doi.org/10.1201/9781420015188.ch6 